\title{
REVIEW
}

\section{Pituitary tumors and the risk of other malignancies: is the relationship coincidental or causal?}

\author{
Sandra Pekic ${ }^{1,2}$, Marko Stojanovic ${ }^{1,2}$ and Vera Popovic ${ }^{1}$ \\ 1 School of Medicine, University of Belgrade, Belgrade, Serbia \\ ${ }^{2}$ Clinic for Endocrinology, Diabetes and Metabolic Diseases, University Clinical Center Belgrade, Belgrade, Serbia
}

Correspondence should be addressed to V Popovic: popver@gmail.com

\begin{abstract}
Pituitary adenomas are benign neoplasms of the pituitary. The most prevalent are prolactinomas and non-functioning pituitary adenomas, followed by growth hormoneand ACTH-secreting adenomas. Most pituitary adenomas seem to be sporadic and their persistent growth is very atypical. No molecular markers predict their behavior. The occurrence of pituitary adenomas and malignancies in the same patient can be either pure coincidence or caused by shared underlying genetic susceptibility involved in tumorigenesis. Detailed family history on cancers/tumors in the first, second and third generation of family members on each side of the family has been reported in a few studies. They found an association of pituitary tumors with positive family history for breast, lung and colorectal cancer. We have reported that in about $50 \%$ of patients with pituitary adenomas, an association with positive family history for cancer has been found independent of secretory phenotype (acromegaly, prolactinoma, Cushing's disease or non-functioning pituitary adenomas). We also found earlier onset of pituitary tumors (younger age at diagnosis of pituitary tumors) in patients with a strong family history of cancer. In our recent unpublished series of 1300 patients with pituitary adenomas, 6.8\% of patients were diagnosed with malignancy. The latency period between the diagnosis of pituitary adenoma and cancer was variable, and in 33\% of patients, it was longer than 5 years. Besides the inherited trophic mechanisms (shared underlying genetic variants), the potential influence of shared complex epigenetic influences (environmental and behavioral factors - obesity, smoking, alcohol intake and insulin resistance) is discussed. Further studies are needed to better understand if patients with pituitary adenomas are at increased risk for cancer.
\end{abstract}

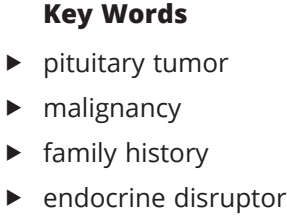

Endocrine Oncology (2022) 2, R1-R13

\section{Introduction}

Pituitary adenomas are usually benign neoplasms arising from anterior pituitary cells, grow slowly and usually change little in size over many years. The autopsy and MRI studies showed that $10-15 \%$ of patients with no history of pituitary disease had previously undiagnosed pituitary tumors, incidentalomas and clinically relevant pituitary tumors (Hall et al. 1994, Burman \& Saeger 2006). Epidemiological studies show an increased incidence and prevalence of pituitary tumors in the general population, with approximately 1 case per 1000 of the general (c) 2022 The authors Published by Bioscientifica Ltd.

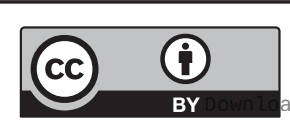

This work is licensed under a Creative Commons Attribution 4.0 International License. 
population (Daly \& Beckers 2020). The most prevalent are prolactin-secreting adenomas (50-60\%), non-functioning pituitary adenomas (20-40\%), growth hormone-secreting adenomas (10-15\%) and adrenocorticotropin-secreting adenomas (5-8\%) (Molitch 2017, Daly \& Beckers 2020, Melmed 2020, Ho et al. 2021). In summary, pituitary adenomas are common in the general population, majority are benign tumors and they change little in size over many years. Recently it has been shown that non-functioning microadenomas ( $<1 \mathrm{~cm}$ in size) have a mean and median time to growth of 38.1 and 24.5 months, respectively (Han et al. 2021). A small proportion of pituitary tumors behaves aggressively, that is affect the surrounding structures.

The number of genetic factors linked to pituitary tumors is very small. Usually, pituitary tumors may be diagnosed as a part of hereditary endocrine neoplasia, such as multiple endocrine neoplasia types 1 and 4, familial isolated pituitary adenomas, succinate dehydrogenase mutations (SDHA, SDHB, SDHC, SDHD, MAX, TMEM 127) and other conditions (Mc Cune Albright Sy, Carney complex, neurofibromatosis type 1, von Hippel-Lindau syndrome and tuberous sclerosis complex (TSC1 and TSC2). In this review, we will not discuss these hereditary syndromes.

Here, we will discuss risk factors for tumorigenesis for both pituitary tumors and cancers. We will not discuss the role of hormones in the progression of cancers. It is known that hormones stimulate the proliferation of cancer cells and promote tumors growth but are not carcinogens.

\section{The risk of malignancy in patients with sporadic pituitary adenomas}

It is still a matter of debate whether patients with pituitary adenomas are at increased risk of malignant tumors (Popovic et al. 1998, Boguszewski \& Ayuk 2016, Olsson et al. 2017). The incidence of malignancy was studied in patients with chronic excess of growth hormone (acromegaly) in particular, while this topic has been rarely studied in patients with non-functioning pituitary adenoma and prolactinomas (Popovic et al. 1998, Erfurth et al. 2001, Minniti et al. 2005, Norberg et al. 2008, Sattler et al. 2012, Child et al. 2015, Boguszewski \& Ayuk 2016, Olsson et al. 2017, Terzolo et al. 2017, Battistone et al. 2021).

\section{Acromegaly and risk for malignancy}

This association of growth hormone (GH)/insulin-like growth factor 1 (IGF-1) axis and cancer risk is complex. Experimental studies showed that GH and IGFs have pro- mitogenic and anti-apoptotic properties and have an important role in growth, metabolism, control of cell cycle and chemoresistance (Seccareccia \& Brodt 2012, Strous et al. 2020, Kasprzak 2021). Experimental studies show that $\mathrm{GH}$ is permissive for neoplastic colon growth and induces colon DNA damage independent of IGF-1 (Chesnokova et al. 2016, Chesnokova et al. 2019). Growth hormone mediates the colon microenvironment by suppressing tumor-suppressor genes, such as p53 and adenomatous polyposis coli (APC) in colon cells, with subsequent decreased p21 expression and apoptosis (Chesnokova et al. 2016). GH excess enables cell survival and motility, while administration of a GH receptor blocker (pegvisomant) induces these tumor-suppressor genes (p53 and APC) (Chesnokova et al. 2016). GH in colon cells also decreases DNA repair and increases DNA damage accumulation by direct effect, independently of IGF-1, thus promoting chromosomal instability (Chesnokova et al. 2019). Overall although GH may have a role in the progression of malignancy, it does not induce malignancy.

Many studies showed that high-normal serum IGF-1 levels may be associated with an increased risk of malignancy in the general population (Pollak et al. 2004, Renehan et al. 2004, Samani et al. 2007, Murphy et al. 2020, Watts et al. 2021). Also, studies on hypopituitary experimental animals (dwarf mice, GH receptor/BP knockout mice) showed a lower incidence of malignancy and increased longevity (Bartke \& Brown-Borg 2004, Ikeno et al. 2009, Bartke et al. 2016, Duran-Ortiz et al. 2021). Similar results were shown in some patients with congenital hypopituitarism due to PROP-1 mutation (few people of Krk) or congenital IGF-1 deficiency (Shevah \& Laron 2007, Krzisnik et al. 2010, Guevara-Aguirre et al. 2011). However, cases from the literature illustrate that even severe isolated GH deficiency does not protect completely from the development of malignancy (Aguiar-Oliveira et al. 2010). We reported a 42-year-old female with combined familial congenital hypopituitarism (PROP1 mutation) and severe GH deficiency, who died from cancerous leptomeningitis due to advanced ovarian cancer (Vujovic et al. 2016). She had six close relatives with malignant disease. We also managed a 71-year-old male patient with congenital hypopituitarism with lifelong untreated GH deficiency, who died from disseminated renal cancer. His sister had a history of breast cancer. Both of our patients with GH deficiency had family history of malignancy, the risk factor which we will later discuss in more detail.

In the clinical settings of chronic supra-physiological growth hormone and IGF-1 levels in patients with acromegaly, the risk to development of malignancies is 
still controversial (Loeper \& Ezzat 2008, Boguszewski \& Ayuk 2016, Boguszewski \& Boguszewski 2019). Cancerrelated mortality in active acromegalic patients shows conflicting results. In some studies, mortality is increased, while in others, it is not (Orme et al. 1998, Popovic et al. 1998, Holdaway et al. 2004, Kauppinen-Makelin et al. 2005, Sherlock et al. 2009, Colao et al. 2014, Terzolo et al. 2017, Esposito et al. 2018, 2021). Large epidemiological and observational studies on all cancers, colorectal cancer and thyroid cancers show inconsistent results (Orme et al. 1998, Jenkins \& Besser 2001, Gullu et al. 2010, Battistone et al. 2021).

A large nationwide population-based study from Sweden investigated the incidence of benign and malignant tumors in 1296 patients with acromegaly (Esposito et al. 2021). The authors reported increased risk of both benign (more than two-fold) and malignant tumors (by 30\%), especially colorectal and anal cancer (50\% higher), as well as kidney and ureteral cancer (fourfold higher) in acromegaly in comparison with the Swedish general population. The incidence of thyroid cancer was not increased in this study (only 3 cases were recorded in 1296 acromegalics). Age at acromegaly diagnosis was significantly related to increased cancer risk, while gender, hypopituitarism or diabetes mellitus were not associated with cancer risk (Esposito et al. 2021).

An interesting pilot study investigated the possible protective role of metformin on the development of colonic polyps in 58 patients with acromegaly (Albertelli et al. 2021). A significant negative association between metformin intake and colonic polyps was demonstrated: $57 \%$ of patients without polyps were treated with metformin, while only $24 \%$ of patients with polyps (including three adenocarcinomas) were treated with metformin. The results of this study could suggest a protective role of metformin but need to be confirmed in larger studies.

As for differentiated thyroid cancer in patients with acromegaly, there is some evidence for the role of genetic events for the onset of thyroid cancer with no correlation with disease activity or GH/IGF-1 levels. Mian et al. proposed that risk for thyroid cancer might be associated with BRAF mutations and aryl hydrocarbon receptor (AhR) overexpression (Mian et al. 2014). BRAF V600E was found in $70 \%$ of the papillary thyroid cancers, and AhRinteracting protein (AIP) was expressed more in papillary thyroid cancers particularly carrying BRAF mutations than in normal tissue, irrespective of acromegaly activity (Mian et al. 2014). The acromegalic patients with differentiated thyroid cancer were older and more often female, with similar levels of GH/IGF-1 compared with acromegalic patients without thyroid cancer (Mian et al. 2014). Other studies showed much lower prevalence of BRAF V600E mutations (14.3\%) and NRAS mutations (21.4\%) in acromegalic patients with thyroid cancer (Aydin et al. 2016). The impact of these mutations in promoting thyroid carcinoma in acromegaly remains to be defined in further studies. Current data do not recommend screening for thyroid cancer at diagnosis of acromegaly. In those patients with palpable thyroid nodule and other risk factors for thyroid cancer, the recommendations are the same as for the general population (Giustina et al. 2020).

The Italian nationwide multicenter cohort study of 1512 acromegalic patients showed that acromegaly was associated with a moderate increase in cancer risk for all cancers. Multivariate analysis showed that the increased risk of malignancy was not associated with $\mathrm{GH} /$ IGF-1 concentrations or duration of acromegaly (nonsignificant association with duration of acromegaly), but it is associated with age and family history of cancer (Terzolo et al. 2017). Colonoscopy screening in patients with acromegaly at diagnosis showed an increased risk of preneoplastic colonic lesions and colorectal cancer in these patients, compared with the general population, with insulin resistance as a risk factor for colonic polyps (Battistone et al. 2021). Recently, recommendations for screening thyroid and colorectal cancers in patients with acromegaly have been published (Terzolo et al. 2020).

Cancer becomes a leading cause of death in acromegalic patients with improved life expectancy (Arosio et al. 2012, Bogazzi et al. 2013, Mercado et al. 2014, Ritvonen et al. 2016, Maione et al. 2017, Bolfi et al. 2018). The cancer type includes different malignancies that are not traditionally related to acromegaly (such as colon and thyroid cancer): anaplastic thyroid carcinoma, glioblastoma, ovarian adenocarcinoma, uterine, lung, liver, prostate, breast, ovary, brain, gastric, pancreatic, hematological and melanoma (Orme et al. 1998, Holdaway et al. 2004, Kauppinen-Makelin et al. 2005, Sherlock et al. 2009, Colao et al. 2014, Bolfi et al. 2018, Esposito et al. 2018). These different cancer types are typically associated with age, genetic and environmental factors (Bolfi et al. 2018).

Recently, experts in the management of acromegaly published recommendations regarding comorbidities in acromegaly (Giustina et al. 2020). It is suggested that acromegaly patients undergo screening colonoscopy at diagnosis, but there are no conclusive data about screening frequency (Giustina et al. 2020). There are some difficulties in cancer diagnosis in patients with acromegaly. Colonoscopy can be technically challenging in these 
patients due to dolichocolon and tortuous bowel loops and should be performed by an experienced gastroenterologist (Gadelha et al. 2019). Also, only 25\% of patients had a colonoscopy at diagnosis of acromegaly, while others had first colonoscopy after a mean of 9 years after acromegaly diagnosis (Parolin et al. 2018). It remains unknown if this increased incidence of some types of malignancy in acromegaly (colorectal cancer) is due to more screening (Gadelha et al. 2019).

\section{Non-functioning pituitary adenoma and risk for malignancy}

The incidence of malignancy in patients with nonfunctioning pituitary adenoma has been sparsely studied (Popovic et al. 1998, Olsson et al. 2017, Hammarstrand et al. 2018). Previous analysis of our database with 469 patients with pituitary adenoma showed that the overall incidence of malignancy in patients with acromegaly and nonfunctioning pituitary adenomas was significantly increased (Table 1) (Popovic et al. 1998). In our recent unpublished larger series of 1300 patients with pituitary adenomas, 88 patients $(6.8 \%)$ were diagnosed with malignancy, almost half of them $(n=43)$ had non-functioning pituitary adenoma. Clinical characteristics and type of malignancy in these patients are presented in Table 2. The latency period between the diagnosis of pituitary adenoma and cancer was variable, and in 33\% of patients, it was longer than 5 years. These data are in accordance with the large study of the Swedish Cancer Register (Olsson et al. 2017). These authors demonstrated that patients with non-functioning pituitary adenoma $(n=2795)$ have an increased overall risk of developing malignancies (only men) and increased incidence of neoplasms of the brain, skin and melanoma (Olsson et al. 2017). Another study of 426 patients with non-functioning pituitary adenoma did not confirm increased incidence of malignant tumors, either in patients with or without GH replacement therapy (Hammarstrand et al. 2018).

A recently published study in patients with nonfunctioning pituitary adenoma analyzed chromosomal and oxidative DNA damage (Bitgen et al. 2021). These authors reported increased chromosomal DNA damage parameters in these patients, which might be associated with possible cancer risk in these patients. Similar results of increased genome damage were published in acromegaly and prolactinoma (Hamurcu et al. 2011, Bayram et al. 2014, Bitgen et al. 2016).

We recently encountered a 57-year-old male patient with a background history of breast cancer who presented with visual disturbance. He was initially diagnosed with a ductal breast carcinoma 2 years prior and was treated with mastectomy. Post-operatively, he was commenced on tamoxifen. Consecutively he was diagnosed with a non-functioning silent gonadotroph pituitary tumor. His mother suffered from breast cancer, and because of the genetic risk, he was evaluated for breast cancer gene 1 (BRCA1)/breast cancer gene 2 (BRCA2) mutation and was positive.

There are 21 reported cases and series in the literature on metastasis of malignancy to a pituitary non-secretinggonadotroph adenoma, reminding us of the coexistence of two diagnoses and the need for the correct solution of the relationship (Barbosa et al. 2020).

Table 1 Frequency of cancer in patients with non-functioning pituitary tumour, prolactinoma and acromegaly compared with the general population (GP) and with the internal control group (Graves' disease-GD). Reproduced with permission from John Wiley and Sons Ltd from Popovic et al. (1998). (c) 1998.

\begin{tabular}{|c|c|c|c|c|c|c|c|}
\hline \multirow[b]{2}{*}{ Tumor } & \multirow{2}{*}{$\begin{array}{c}\text { Number of } \\
\text { patients }\end{array}$} & \multirow[b]{2}{*}{ Patient-years } & \multirow[b]{2}{*}{ Observed } & \multicolumn{2}{|c|}{ Malignancy } & \multirow[b]{2}{*}{ SIR-GP $(95 \% \mathrm{CI})$} & \multirow[b]{2}{*}{ SIR-GD $(95 \% \mathrm{CI})$} \\
\hline & & & & Expected (GP) & Expected (GD) & & \\
\hline \multicolumn{8}{|c|}{ Non-functioning } \\
\hline All & 151 & 609 & 11 & 2.56 & 2.70 & $3.91(1.88-7.19)^{a}$ & $4.07(2.03-7.29)^{a}$ \\
\hline Female & 86 & 371 & 4 & 1.19 & 1.29 & $2.52(0.52-7.36)$ & $3.10(0.84-7.94)$ \\
\hline Male & 65 & 238 & 7 & 1.26 & 2.31 & $5.56(2.23-11.45)^{a}$ & $3.03(1.22-6.24)^{a}$ \\
\hline \multicolumn{8}{|c|}{ Prolactinoma } \\
\hline All & 98 & 522 & 2 & 2.19 & 2.32 & $0.91(0.11-3.29)$ & $0.86(0.10-3.10)$ \\
\hline Female & 67 & 366 & 2 & 1.17 & 1.28 & $1.71(0.21-6.17)$ & $1.56(0.19-5.64)$ \\
\hline Male & 31 & 156 & 0 & 0.83 & 1.51 & $0-$ & $0-$ \\
\hline \multicolumn{8}{|c|}{ Acromegaly } \\
\hline All & 220 & 1546 & 23 & 6.49 & 6.86 & $3.39(2.12-5.12)^{a}$ & $3.21(2.01-4.85)^{a}$ \\
\hline Female & 137 & 936 & 14 & 2.99 & 3.26 & $4.35(2.31-7.44)^{a}$ & $3.99(2.12-6.82)^{a}$ \\
\hline Male & 83 & 610 & 9 & 3.23 & 5.92 & $2.78(1.27-5.28)^{a}$ & 1.52 (0.70-2.89) \\
\hline \multicolumn{8}{|l|}{ a $P<0.01$} \\
\hline \multicolumn{2}{|c|}{$\begin{array}{l}\text { https://eo.bioscientifica.com } \\
\text { https://doi.org/10.1530/EO-21-0033 }\end{array}$} & \multicolumn{2}{|c|}{$\begin{array}{l}\text { (c) } 2022 \text { The au } \\
\text { Published by Bioscientific }\end{array}$} & $\begin{array}{l}\text { ors } \\
\text { tdd. }\end{array}$ & & \multicolumn{2}{|c|}{$\begin{array}{l}\text { This work is licensed under a Creative Commons } \\
\text { Attribution } 4.0 \text { International License. }\end{array}$} \\
\hline
\end{tabular}


Table 2 Clinical characteristics and type of malignancy in patients with pituitary adenoma.

\begin{tabular}{l}
\hline \\
\hline$n$ \\
Sex (F/M) \\
Age at PA diagnosis $(\mathrm{X} \pm$ S.E.) \\
Age at Mg diagnosis $(\mathrm{X} \pm$ S.E.) \\
Type of malignancy \\
Breast cancer \\
Cervical cancer \\
Colorectal cancer \\
Thyroid cancer \\
Lung cancer \\
Endometrial cancer \\
Prostatic cancer \\
Renal cancer \\
Basalioma \\
Leukaemia \\
Neuroendocrine cancer \\
Other cancers \\
Total
\end{tabular}

\begin{tabular}{c}
\hline Non-functioning PA \\
\hline 43 \\
$26 / 17$ \\
$55.2 \pm 2.2$ \\
$53.5 \pm 2.3$
\end{tabular}

\begin{tabular}{c}
\hline Acromegaly \\
\hline 21 \\
$12 / 9$ \\
$48.3 \pm 2.9$ \\
$53.2 \pm 3.2$
\end{tabular}

\begin{tabular}{c}
\hline Prolactinoma \\
\hline 20 \\
$10 / 10$ \\
$49.1 \pm 2.8$ \\
$50.4 \pm 3.2$
\end{tabular}

\begin{tabular}{c}
\hline Morbus Cushing \\
\hline 4 \\
$1 / 3$ \\
$49.0 \pm 7.0$ \\
$58.8 \pm 8.1$
\end{tabular}

\begin{tabular}{c}
\hline Total \\
\hline 88 \\
$49 / 39$ \\
$51.9 \pm 1.5$ \\
$53.0 \pm 1.6$
\end{tabular}

Breast cancer

Lung cancer

Endometrial cance

Prostatic cancer

Basalioma

\begin{tabular}{cc}
10 & 4 \\
9 & \\
4 & - \\
1 & 5 \\
5 & - \\
1 & 2 \\
3 & - \\
2 & 1 \\
- & - \\
2 & 1 \\
2 & - \\
7 & 9 \\
46 (in 43 patients) & 22 (in 21 patients) \\
\hline
\end{tabular}

$\begin{array}{r}1 \\ 4 \\ 3 \\ 1 \\ 2 \\ 1 \\ - \\ - \\ 3 \\ - \\ 1 \\ 4 \\ 20 \\ \hline\end{array}$

\begin{tabular}{cc}
- & 15 \\
1 & 14 \\
1 & 8 \\
1 & 8 \\
- & 7 \\
- & 4 \\
1 & 4 \\
- & 3 \\
- & 3 \\
- & 3 \\
& 3 \\
- & 20 \\
4 & 92 (in 88 patients) \\
\hline
\end{tabular}

Mg, malignancy; PA, pituitary adenoma.

\section{Prolactinoma and risk for malignancy}

Prolactinoma is a very common type of pituitary tumor. There are experimental data indicating that prolactin might play a role in progression and invasion of several cancer types, especially breast cancer (Clevenger et al. 2003, Liby et al. 2003). Several case reports of breast cancer in both females and males with prolactinoma confirm experimental data (Forloni et al. 2001, Sato et al. 2007, Mallawaarachchi et al. 2011, Zheng et al. 2017, BettencourtSilva et al. 2018, Hao et al. 2020). Both diagnoses were either diagnosed simultaneously or in the majority, with a significant latency period up to 32-36 years questioning the role of hyperprolactinemia in inducing cancer. Epidemiological studies that have examined the relationship between prolactin levels and all-cause cancer and/or breast cancer reported inconsistent results (Tworoger et al. 2006, 2013, Dekkers et al. 2010, 2015, Berinder et al. 2011, Tikk et al. 2015, Wang et al. 2016, SotoPedre et al. 2017, Pekic et al. 2019a).

A population-based cohort study that investigated cancer risk in patients with hyperprolactinemia reported a small increase in overall cancer risk, mainly attributed to upper gastrointestinal cancer and hematopoietic cancer, but the risk of breast cancer was not increased, and the risk of prostate cancer was reduced (Berinder et al. 2011). A large proportion of patients with breast cancer have a family history of breast or ovarian cancer. The most common gene mutations associated with breast cancer are BRCA1 and BRCA2 mutations. Bettencourt-Silva et al. reported a case of a 25-year-old female with giant prolactinoma, germline BRCA1 mutation and a family history of breast cancer (mother and maternal aunt) (Bettencourt-Silva et al. 2018). This case is in line with our data that there is a strong association between prolactinoma and family history of breast cancer (Table 3) (Pekic et al. 2019b).

\section{Prolactinoma in two patients with uncommon disease}

We have previously reported two patients who were found to have two rare conditions: one male patient had developmental hypothalamic-pituitary disorder: Kalman syndrome (KS) and the other female patient had congenital hypopituitarism and both were diagnosed with a pituitary tumor (prolactinoma) in adulthood (Doknic et al. 2012).

A male patient with hypogonadotropic hypogonadism - KS due to KAL 2 gene mutation (loss of function of fibroblast growth factor receptor 1 - FGF R 1 mutation) and a female patient with congenital hypopituitarism (combined pituitary hormone deficiency - CPHD) due to PROP1 (pituitary homeobox protein prophet of the Pit 1 gene mutation) who both developed in adulthood welldifferentiated pituitary adenoma - prolactinoma. The latency period before the diagnosis of prolactinoma for the male patient with KS was 25 years, while for the female patient with PROP1 mutation was 10 years.

To our knowledge, there is only one recent report by Suzuki et al. (2021) who showed that the PIT-1 $\beta$ mutation can cause CPHD through a novel genetic mechanism, such 
Table 3 Clinical characteristics and history of malignancy in patients with pituitary adenoma and their families. Reprinted by permission from Springer Nature Ltd., Pekic S, Soldatovic I, Miljic D, Stojanovic M, Doknic M, Petakov M \& Popovic V, Hormones and Cancer, Familial cancer clustering in patients with prolactinoma, (c) 2019.

\begin{tabular}{l}
\hline$n$ \\
Male sex (\%) \\
Age (mean \pm s.D., years) \\
Actual age \\
At diagnosis of PA \\
Malignancy in the family (\%) \\
$1^{\circ}$ rel \\
Parents \\
Siblings \\
2 and $3^{\circ}$ rel \\
All degrees relc \\
Breast cancer in $1^{\circ}$ rel (\%) \\
Lung cancer in $1^{\circ}$ rel (\%) \\
Colon cancer in $1^{\circ}$ rel (\%) \\
Breast cancer in 2 and $3^{\circ}$ rel (\%) \\
Lung cancer in 2 and $3^{\circ}$ rel (\%) \\
Colon cancer in 2 and $3^{\circ}$ rel (\%) \\
\hline
\end{tabular}

\begin{tabular}{c}
\hline Acromegaly \\
\hline 220 \\
$86(39.1)^{p}$ \\
$54.9 \pm 13.5^{p}$ \\
$47.2 \pm 13.6 p, n$ \\
$96(43.6)$ \\
$55(25.0)$ \\
$41(18.6)$ \\
$15(6.8)^{p}$ \\
$55(25.0)^{p}$ \\
$14(6.4)$ \\
$4(1.8)^{n, p}, b$ \\
$9(4.1)$ \\
$6(2.7)$ \\
$12(5.5)^{p}$ \\
$14(6.4)$ \\
$5(2.3)$ \\
\hline
\end{tabular}

\begin{tabular}{c}
\hline Prolactinoma \\
\hline 372 \\
$96(25.8)^{a, n}$ \\
$41.1 \pm 13.8^{a, n}$ \\
$35.4 \pm 13.0^{a, n}$ \\
$192(51.6)^{n, b}$ \\
$77(20.7)^{n}$ \\
$66(17.7)^{n, b}$ \\
$11(3.0)^{a, n}$ \\
$144(38.7)^{a, n}$ \\
$29(7.8)$ \\
$19(5.1)^{a}$ \\
$9(2.4)$ \\
$13(3.5)$ \\
$41(11.0)^{a, n}$ \\
$37(9.9)^{n}$ \\
$21(5.6)$
\end{tabular}

\begin{tabular}{c}
\hline NFPA \\
\hline 470 \\
$204(43.4)^{\mathrm{p}}$ \\
$55.5 \pm 16.5^{\mathrm{p}}$ \\
$51.2 \pm 16.1 \mathrm{a}, \mathrm{p}$ \\
$207(44.0)^{\mathrm{p}, \mathrm{b}}$ \\
$140(29.8)^{\mathrm{p}}$ \\
$110(23.4)^{\mathrm{p}, \mathrm{b}}$ \\
$34(7.2)^{\mathrm{p}}$ \\
$99(21.1)^{\mathrm{p}}$ \\
$32(6.8)$ \\
$29(6.2)^{\mathrm{a}, \mathrm{b}}$ \\
$16(3.4)$ \\
$16(3.4)$ \\
$19(4.0)^{\mathrm{p}}$ \\
$18(3.8)^{\mathrm{p}}$ \\
$25(5.3)$ \\
\hline
\end{tabular}

$\frac{\text { Total }}{1062}-$

$P$

$50.6 \pm 16.5 \quad 0.001$ $44.9 \pm 16.2 \quad 0.001$ $495(46.6) \quad 0.056$ $272(25.6) \quad 0.011$ $217(20.4) \quad 0.098$ $60(5.6) \quad 0.020$ $298(28.1) \quad 0.001$ $75(7.1) \quad 0.673$ $52(4.9) \quad 0.046$ $34(3.2) \quad 0.507$ $35(3.3) \quad 0.866$ $72(6.8) \quad 0.001$ $69(6.5) \quad 0.002$ $51(4.8) \quad 0.140$

Single group by group comparisons, with correction $(P<0.05)$ : aAcromegaly; pProlactinoma; nNFPA; bSingle group by group comparisons, without correction $(P<0.05)$; cSome patients are represented in more than one category if having both a first-degree and second-and third-degree relatives with a cancer.

$1^{\circ}$, first-degree relatives; 2 and $3^{\circ}$, second- and third-degree relatives; NFPA, non-functioning pituitary adenoma; PA, pituitary adenoma; rel, relatives.

as PIT-1 $\beta$ overexpression, and that POU1F1 mutation might be associated with a prolactinoma (Suzuki et al. 2021). These authors state that it is unclear how the PIT- $1 \beta$ mutation is associated with the development of prolactinoma and that there is no clear explanation regarding the possible mechanism for the association between developmental hypothalamic-pituitary disorders with the development of pituitary tumors. Are they separated and potentially unrelated disease processes that may occur concomitantly or not is to be shown in further studies We should not dismiss reports that mutations in early developmental transcription factor such as SOX2 are associated with slowly progressing hypothalamo-pituitary tumor (Alatzoglou et al. 2011). Also, it has been shown recently that activating mutations in BRAF disrupt the hypothalamo-pituitary axis development leading to hypopituitarism, while somatic mutation of BRAF pV600E is a driver of benign tumor, papillary craniopharyngioma and is identified in corticotroph adenomas (Gualtieri et al. 2021). Mutations in BRAF have a high occurrence rate in different cancers. So the same underlying genetic driver has different unknown roles in different cell types leading to tumorigenesis (Gualtieri et al. 2021).

Occam razor principle is to "choose the simplest from a set of models of a given phenomenon that is in accordance with evidence' (Wildner 1999). The patient with PROP1 mutation in her family had an occurrence of multiple malignancies such as breast cancer, melanoma and lung cancers while the mother of the patient with KS suffered from breast cancer.

\section{Studies on familial cancer risk in patients with pituitary adenoma}

The association of pituitary adenoma and positive family cancer history has been demonstrated in few studies (Hemminki et al. 2007, Couldwell \& Cannon-Albright 2014, Terzolo et al. 2017, Pekic et al. 2019b). The epidemiological study on incidence and familial risks in pituitary adenoma and associated tumors has been reported in the Swedish Family-Cancer Database of 10.5 million individuals containing families with parents and offspring, included 3239 patients with pituitary tumor (Hemminki et al. 2007). Hemminki et al. reported that among tumors associated with pituitary adenoma in families, breast and colorectal cancer were prominent. Second large epidemiological study analyzed the Utah Population Database with more than 7.5 million individuals, including 575 patients with pituitary adenoma (Couldwell \& Cannon-Albright 2014). The analysis of this database showed an association of pituitary adenoma with excess of several cancers (prostate and other cancer sites) among their relatives. Our large study on 1062 patients with pituitary adenomas showed that family history of malignancy should not be dismissed as a risk for pituitary adenoma development (Pekic et al. 
$2019 b)$. We demonstrated that almost half of patients (46.6\%) with pituitary adenoma of any type (prolactinoma, non-functioning pituitary adenoma and acromegaly) had a family history of malignancy (Table 3) (Pekic et al. $2019 b$ ). In our series, we demonstrated a strong association between prolactinoma and family history of breast and lung cancers. Also, colorectal cancer was associated with all types of pituitary adenomas. An interesting observation in our study was that younger age and female sex were more prevalent in pituitary adenoma patients with positive family cancer history (Pekic et al. 2019b).

The importance of detailed family history is reported in recently published 2021 National Comprehensive Cancer Network Guidelines principles of genetic risk assessment and counseling in patients with sporadic and hereditary neuroendocrine and adrenal tumors (Shah et al. 2021). These recommendations included in pre-test counseling detailed personal cancer/tumor history (including age at diagnosis and treatment) and detailed family history (including cancers/tumors and age at diagnosis, as well as clinical symptoms that can indicate underlying endocrine neoplasia) in first-, second- and third-degree family members on each side of the family (Shah et al. 2021).

\section{Genomic profile of pituitary tumors}

Accumulation of genetic alterations is involved in cancer pathogenesis. Various cancers use different molecular pathways. Today, it is recognized that cancer evolves in a stepwise fashion and it may take decades to progress (Shain et al. 2015). It is also believed that the accumulation of genetic defects results in monoclonal expansion of pituitary adenomas. Most pituitary tumors are aneuploid suggesting genetic instability. Analysis of pituitary adenomas using whole-exome sequencing shows sporadic mutations at relatively low prevalence (Bi et al. 2017). In that study, genomic profile of a large cohort of pituitary tumors demonstrated high variability in somatic copy number profiles and genomic disruption. None of the molecular studies could identify critical molecular signatures associated with pituitary tumorigenesis. What is identified are frequent changes in genes in the DNA damage response pathway, cell cycle and chromatic modifier families. Some somatic mutations, like GNAS gain-of-function mutation identified in 30\% of somatotropinomas, GPR101 mutation identified in $4 \%$ of somatotropinomas and USP8 mutation identified in $40 \%$ of corticotrophinomas, are not clearly associated with tumor behavior (Reincke et al. 2015, Chen et al. 2018, Sbiera et al. 2019). Some pituitary adenomas express no chromosomal alterations, while the other has widespread genomic disruptions, functioning pituitary adenomas in particular (Bi et al. 2018, Hage et al. 2018). Widespread genomic alterations are present in silent corticotroph adenoma and prolactinoma in particular (Bi et al. 2017).

The ability to accurately identify molecular signatures associated with histopathology and clinical outcomes is still not possible. Although a study by Lasolle et al. did show that the quantity of copy number variations is dependent on tumor type (higher in prolactinomas) compared to other tumors and another study showed that all functional pituitary tumors demonstrated higher variability in copy number profiles (Bi et al. 2017, Lasolle et al. 2020). As for aggressive and malignant pituitary tumors, lactotroph tumors are the second most frequent after corticotrophinomas (McCormack et al. 2018). Gene expression analysis of lactotroph tumors showed significant deregulation of 140 genes (120 genes showed increased expression, while 20 genes showed reduced expression) (Wierinckx etal. 2018). There is a sex-specific gene landscape, with some genes expressed at higher levels in males compared with females: (1) two growth factors, FGF13 and VEGFD involved in angiogenesis, cell growth/proliferation and control of cellular movement/morphology, VEGFD involved also in cell cycle control; (2) cancer-testis antigen (CTAG2) involved in cellular movement, highly expressed also in invasive breast cancer; (3) creatine transporter (SLC6A8) involved in creatine metabolism (Wierinckx et al. 2018). These findings could explain sex-specific differences in lactotroph adenoma behavior (men have a higher grade of lactotroph adenoma, more resistance to treatment, worse prognosis). These authors also observed that chromosomic abnormalities were numerous in aggressive than nonaggressive tumors, implying much pronounced genetic instability and tumor aggressiveness. Another important finding of these authors is a reduced estrogen receptor alpha $(\mathrm{ER} \alpha)$ protein expression in male lactotroph tumors (Delgrange et al. 2015, Wierinckx et al. 2018, Trouillas et al. 2019). It is well-known that a correlation between low $\mathrm{ER} \alpha$ protein expression in breast tumor and the grade of malignancy exists (Krol et al. 2018).

Recently, a multi-omics analysis of 134 pituitary tumors identified chromosomal alterations in $23 \%$ of the genome been altered (Neou et al. 2020). Again, the number of alterations was higher in functional tumors. This integrated pangenomic analysis of pituitary tumors identified different molecular classes of these tumors allowing a new, pangenomic classification with new subtypes, with implications for the clinicians.

An investigation of telomere length in pituitary adenoma was recently published (Heaphy et al. 2020). 
Shortened, dysfunctional telomeres are often detected in precancerous lesions and invasive cancers, contributing to genomic instability. The study of 106 pituitary adenomas demonstrated that short telomere lengths were detected in half of the cases (59.4\%) (Heaphy et al. 2020). Also, $36 \%$ of recurrent pituitary adenomas had alternative lengthening of telomeres. The authors concluded that telomere alterations are prevalent in pituitary adenomas, contributing to genomic instability (Heaphy et al. 2020). As has been reported many years ago, it still remains uncertain whether the molecular defects that have been found within the pituitary tumor are acquired and if they are pathogenic (Levy \& Lightman 2003, Levy 2011).

In summary, the accumulation of genetic alterations is involved both in pituitary tumor and cancer pathogenesis.

\section{Environmental risk factors}

Age, family history and hereditary cancer predisposition syndromes present non-modifiable cancer risk factors. However environmental insults are modifiable, that is avoidable cancer risk factors. Metabolic disturbances (obesity and diabetes mellitus) will overtake smoking and alcohol as modifiable cancer risk factors. 'Insulin resistance' (observed in obesity and type 2 diabetes mellitus) does not apply equally to all of insulin's actions. Adverse trophic actions of the high insulin concentration in insulin resistance required to maintain euglycemia have been reported. These trophic actions of increased insulin actions in different tissues are in particular observed in ovaries in patients with polycystic ovary syndrome (Huang-Doran et al. 2021).

Environmental risk factors were long accepted as contributors to increased risk of several malignancies. More recently, a considerable scientific interest was directed toward environmental pollutants and endocrine disruptor chemicals as risk factors in pituitary adenoma pathogenesis or promotion. The most investigated possible crossroad for environmental toxins (dioxins and heavy metals) and pituitary tumorigenesis is the AIP-AhR pathway. Scientific interest for the nature and function of AIP gene (Aryl hydrocarbon receptorinteracting protein) originated from the discoveries that inactivating germline AIP mutations are associated with occurrence of pituitary adenomas (Alforei \& Korbonits 2014, Lim \& Korbonits 2018). Inactivating AIP mutations lead to pituitary adenoma in $30 \%$, most frequently to somatotropinoma or prolactinoma, often large, invasive and resistant to medical treatment and prone to apoplexy
(Vierimaa et al. 2006, Leontiou et al. 2008, Trivellin \& Korbonits 2011, Lloyd \& Grossman 2014, Pepe et al. 2019). Frequent invasiveness and clinical aggressiveness of AIP mutation-associated pituitary adenoma are in contrast to other monogenetically predisposed pituitary adenoma promoted by the cAMP-PKA pathway activation (such as Carney complex or McCune-Albright syndrome). This suggests different or additional mechanisms in the case of AIP (Pepe et al. 2019). Pituitary adenoma in AIP mutation carriers typically occurs with a low penetrance (Vierimaa et al. 2006, Chahal et al. 2012). This may also indicate that additional environmental or genetical factors might contribute to the risk of pituitary adenoma development in AIP mutation carriers. The first identified partner molecule of AIP protein was a nuclear receptor AhR, best known for its role in binding environmental toxins. Thus, environmental pollution was investigated as one of the possible factors in pituitary adenoma pathogenesis or promotion via AIP-AhR pathway. This problem was investigated in vitro on pituitary cell lines and in acromegaly patients (Pesatori et al. 2008, Cannavò et al. 2010, Cannavo et al. 2016, 2017, Fortunati et al. 2017, Tapella et al. 2017). Several in vitro studies demonstrated a relationship between GH3 cells exposure to toxins acting via AhR and an increase in proliferation (Tapella et al. 2017). On an epidemiological level, a correlation was suggested between exposure to environmental air contaminants and increase in somatotropinoma incidence (Cannavò et al. 2010). However, a direct relationship was not confirmed by investigating the population in a region affected by a major industrial accident with widespread dioxin exposure (Pesatori et al. 2008). A modifying effect of AhR or AIP polymorphisms in addition to contaminant exposure was associated in acromegaly patients with pituitary adenoma size, biological aggressiveness and resistance to somatostatin analogs (Cannavo et al. 2016).

Cadmium is a heavy metal of considerable environmental and occupational concern. Several regulatory agencies classified cadmium compounds as human carcinogens, based on the studies indicating occupational cadmium exposure association with lung cancer. A waker linkage was postulated between cadmium exposure and human prostate and renal cancer (Waalkes et al. 1999). Meanwhile, an association was demonstrated between a single, high-dose exposure to cadmium in Noble rats with a significant increase in pituitary adenoma prevalence, exclusively in pars distalis (Waalkes et al. 1999). The effects of cadmium on pituitary tumorigenesis need further elucidation but might also involve the AhR-AIP pathway since AhR signaling was recently observed to be 
involved in the lung leukocyte proinflammatory cytokine response to cadmium (Kulas et al. 2021).

Bisphenol A (BPA) is a monomer of plastics and epoxy resins widely used in the dentistry and food packaging industry, persistently present in the environment due to its long biological half-life. BPA exposure was identified to present a potential risk factor for breast cancer (Keshavarz-Maleki et al. 2021). On the other hand, high BPA concentrations induce cell growth and prolactin secretion in an estrogen-responsive pituitary tumor cell line (Maruyama et al. 1999, Chun \& Gorski 2000).

Polychlorinated biphenyls (PCBs) are persistent pollutants and pro-tumorigenic in the liver. Although non-dioxin like, these substances were also observed to affect the pituitary AhR pathway. Data on the capacity of PCBs to modulate cell proliferation at the pituitary level signal a potential tumor-promoting role of this pollutant (Raggi et al. 2016).

Endocrine-disrupting chemicals (EDCs) are lowconcentration pollutants from various sources capable of mimicking hormonal actions or affecting endocrine pathways, by interfering with the synthesis, metabolism, binding or cellular responses of natural hormones (Hamid et al. 2021). EDCs have been associated with cancer prevalence, especially breast, prostate and testicular malignancies (Rocha et al. 2021). Xeno-estrogens are one of major EDC classes, attributed to genomic or non-genomic interactions with estrogen receptor. Xeno-estrogens, such as alkylphenols (in particular, nonylphenol) are found to have a proliferative effect on pituitary level (Kochukov et al. 2009). The capability of natural estrogens to influence pituitary tumorigenesis was only observed in higher doses. Thus, weak estrogenic EDCs are unlikely to cause tumorigenesis alone but are more likely to promote the growth of existing pituitary tumors (Fujimoto 2001).

\section{Conclusion}

Data show that dual diagnoses do arise: common (cancers) and uncommon tumors (pituitary tumors) in the same patient. Following the Occam razor principle, we believe that strong family history of malignancy (inherited trophic mechanisms) in our patients in the context of unfavorable environment is the underlying risk factors for the development of cancer and pituitary tumorigenesis.

\section{Declaration of interest}

The authors declare that there is no conflict of interest that could be perceived as prejudicing the impartiality of this review.

\section{Funding}

This study was supported by a grant from the Ministry of Science of Republic of Serbia (Project 175033).

Author contribution statement

S P, M S and V P wrote the paper.

\section{References}

Aflorei ED \& Korbonits M 2014 Epidemiology and etiopathogenesis of pituitary adenomas. Journal of Neurooncology 117 379-394. (https:// doi.org/10.1007/s11060-013-1354-5)

Aguiar-Oliveira MH, Oliveira FT, Pereira RM, Oliveira CR, Blackford A, Valenca EH, Santos EG, Gois-Junior MB, Meneguz Moreno RA, Araujo VP, et al. 2010 Longevity in untreated congenital growth hormone deficiency due to a homozygous mutation in the GHRH receptor gene. Journal of Clinical Endocrinology and Metabolism 95 714-721. (https://doi.org/10.1210/jc.2009-1879)

Alatzoglou KS, Andoniadou CL, Kelberman D, Buchanan CR, Crolla J, Arriazu MC, Roubick M, Moncet D, Martinez-Barbera JP \& Dattani MT 2011 SOX2 haploinsufficiency is associated with slow progressing hypothalamo-pituitary tumours. Human Mutation 32 1376-1380. (https://doi.org/10.1002/humu.21606)

Albertelli M, Nazzari E, Dotto A, Grasso LF, Sciallero S, Pirchio R, Rebora A, Boschetti M, Pivonello R, Ricci Bitti S, et al. 2021 Possible protective role of metformin therapy on colonic polyps in acromegaly: an exploratory cross-sectional study. European Journal of Endocrinology 184 419-425. (https://doi.org/10.1530/EJE-20-0795)

Arosio M, Reimondo G, Malchiodi E, Berchialla P, Borraccino A, De Marinis L, Pivonello R, Grottoli S, Losa M, Cannavò S, et al. 2012 Predictors of morbidity and mortality in acromegaly: an Italian survey. European Journal of Endocrinology 167 189-198. (https://doi. org/10.1530/EJE-12-0084)

Aydin K, Aydin C, Dagdelen S, Tezel GG \& Erbas T 2016 Genetic alterations in differentiated thyroid cancer patients with acromegaly. Experimental and Clinical Endocrinology and Diabetes 124 198-202. (https://doi. org/10.1055/s-0035-1565061)

Barbosa M, Paredes S, Machado MJ, Almeida R \& Marques O 2020 Pituitary apoplexy induced by gonadotropin-releasing hormone agonist administration: a rare complication of prostate cancer treatment. Endocrinology, Diabetes and Metabolism Case Reports 2020 20-0018. (https://doi.org/10.1530/EDM-20-0018)

Bartke A \& Brown-Borg H 2004 Life extension in the dwarf mouse. Current Topics in Developmental Biology 63 189-225. (https://doi.org/10.1016/ S0070-2153(04)63006-7)

Bartke A, List EO \& Kopchick JJ 2016 The somatotropic axis and aging: benefits of endocrine defects. Growth Hormone and IGF Research 27 41-45. (https://doi.org/10.1016/j.ghir.2016.02.002)

Battistone MF, Miragaya K, Rogozinski A, Agüero M, Alfieri A, Ballarino MC, Boero L, Danilowicz K, Diez S, Donoso M, et al. 2021 Increased risk of preneoplastic colonic lesions and colorectal carcinoma in acromegaly: multicenter case-control study. Pituitary $\mathbf{2 4}$ 96-103. (https://doi.org/10.1007/s11102-020-01090-8)

Bayram F, Bitgen N, Donmez-Altuntas H, Cakir I, Hamurcu Z, Sahin F, Simsek Y \& Baskol G 2014 Increased genome instability and oxidative DNA damage and their association with IGF-1 levels in patients with active acromegaly. Growth Hormone and IGF Research 24 29-34. (https://doi.org/10.1016/j.ghir.2013.12.002)

Berinder K, Akre O, Granath F \& Hulting AL 2011 Cancer risk in hyperprolactinemia patients: a population-based cohort study. European Journal of Endocrinology 165 209-215. (https://doi. org/10.1530/EJE-11-0076)

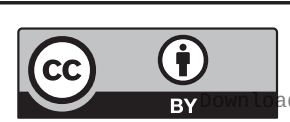

This work is licensed under a Creative Commons Attribution 4.0 International License. 
Bettencourt-Silva R, Queirós J, Pereira J \& Carvalho D 2018 Giant prolactinoma, germline BRCA1 mutation, and depression: a case report. Journal of Medical Case Reports 12 360. (https://doi.org/10.1186/ s13256-018-1890-x)

Bi WL, Greenwald NF, Ramkissoon SH, Abedalthagafi M, Coy SM, Ligon KL, Mei Y, MacConaill L, Ducar M, Min L, et al. 2017 Clinical identification of oncogenic drivers and copy number alterations in pituitary tumors. Endocrinology 158 2284-2291. (https://doi.org/10.1210/en.2016-1967)

Bi WL, Larsen AG \& Dunn IF 2018 Genomic alterations in sporadic pituitary tumors. Current Neurology and Neuroscience Reports 184 (https://doi.org/10.1007/s11910-018-0811-0)

Bitgen N, Donmez-Altuntas H, Bayram F, Cakir I, Hamurcu Z, Diri H, Baskol G, Senol S \& Durak AC 2016 Increased micronucleus, nucleoplasmic bridge, nuclear bud frequency and oxidative DNA damage associated with prolactin levels and pituitary adenoma diameters in patients with prolactinoma. Biotechnic and Histochemistry 91 128-136. (https://doi.org/10.3109/10520295.2015.1101163)

Bitgen N, Bayram F, Hamurcu Z, Ozturk F, Simsek Y, Baskol G, Kurtsoy A \& Donmez-Altuntas H 2021 Chromosomal and oxidative DNA damage in non-functioning pituitary adenomas. Endokrynologia Polska 72 97-103. (https://doi.org/10.5603/EP.a2020.0084)

Bogazzi F, Colao A, Rossi G, Lombardi M, Urbani C, Sardella C, Iannelli A Scattina I, Manetti L, Del Sarto S, et al. 2013 Comparison of the effects of primary somatostatin analogue therapy and pituitary adenomectomy on survival in patients with acromegaly: a retrospective cohort study. European Journal of Endocrinology 169 367-376. (https://doi.org/10.1530/EJE-13-0166)

Boguszewski CL \& Ayuk J 2016 Management of endocrine disease: acromegaly and cancer: an old debate revisited. European Journal of Endocrinology 175 R147-R156. (https://doi.org/10.1530/EJE-16-0178)

Boguszewski CL \& Boguszewski MCDS 2019 Growth hormone's links to cancer. Endocrine Reviews 40 558-574. (https://doi.org/10.1210/er.201800166)

Bolfi F, Neves AF, Boguszewski CL \& Nunes-Nogueira VS 2018 Mortality in acromegaly decreased in the last decade: a systematic review and meta-analysis. European Journal of Endocrinology 179 59-71. (https:// doi.org/10.1530/EJE-18-0255)

Burman H \& Saeger W 2006 Subclinical adenomas in postmortem pituitaries: classification and correlations to clinical data. European Journal of Endocrinology 154 753-758. (https://doi.org/10.1530/eje.1.02107)

Cannavò S, Ferraù F, Ragonese M, Curtò L, Torre ML, Magistri M, Marchese A, Alibrandi A \& Trimarchi F 2010 Increased prevalence of acromegaly in a highly polluted area. European Journal of Endocrinology 163 509-513. (https://doi.org/10.1530/EJE-10-0465)

Cannavo S, Ragonese M, Puglisi S, Romeo PD, Torre ML, Alibrandi A, Scaroni C, Occhi G, Ceccato F, Regazzo D, et al. 2016 Acromegaly is more severe in patients with AHR or AIP gene variants living in highly polluted areas. Journal of Clinical Endocrinology and Metabolism 101 1872-1879. (https://doi.org/10.1210/jc.2015-4191)

Cannavo S, Trimarchi F \& Ferraù F 2017 Acromegaly, genetic variants of the aryl hydrocarbon receptor pathway and environmental burden. Molecular and Cellular Endocrinology 457 81-88. (https://doi. org/10.1016/j.mce.2016.12.019)

Chahal HS, Trivellin G, Leontiou CA, Alband N, Fowkes RC, Tahir A Igreja SC, Chapple JP, Jordan S, Lupp A, et al. 2012 Somatostatin analogs modulate AIP in somatotroph adenomas: the role of the ZAC1 pathway. Journal of Clinical Endocrinology and Metabolism $\mathbf{9 7}$ E1411-E1420. (https://doi.org/10.1210/jc.2012-1111)

Chen J, Jian X, Deng S, Ma Z, Shou X, Shen Y, Zhang Q, Song Z, Li Z, Peng H, et al. 2018 Identification of recurrent USP48 and BRAF mutations in Cushing's disease. Nature Communications 93171. (https://doi.org/10.1038/s41467-018-05275-5)

Chesnokova V, Zonis S, Zhou C, Recouvreux MV, Ben-Shlomo A, Araki T, Barrett R, Workman M, Wawrowsky K, Ljubimov VA, et al. 2016 Growth hormone is permissive for neoplastic colon growth. PNAS 113 E3250-E3259. (https://doi.org/10.1073/pnas.1600561113)
Chesnokova V, Zonis S, Barrett RJ, Gleeson JP \& Melmed S 2019 Growth hormone induces colon DNA damage independent of IGF-1. Endocrinology 160 1439-1447. (https://doi.org/10.1210/en.2019-00132)

Child CJ, Conroy D, Zimmermann AG, Woodmansee WW, Erfurth EM \& Robison LL 2015 Incidence of primary cancers and intracranial tumour recurrences in GH-treated and untreated adult hypopituitary patients: analyses from the hypopituitary control and complications study. European Journal of Endocrinology 172 779-790. (https://doi. org/10.1530/EJE-14-1123)

Chun TY \& Gorski J 2000 High concentrations of bisphenol A induce cell growth and prolactin secretion in an estrogen-responsive pituitary tumor cell line. Toxicology and Applied Pharmacology 162 161-165. (https://doi.org/10.1006/taap.1999.8840)

Clevenger CV, Furth PA, Hankinson SE \& Schuler LA 2003 The role of prolactin in mammary carcinoma. Endocrine Reviews 24 1-27. (https:// doi.org/10.1210/er.2001-0036)

Colao A, Vandeva S, Pivonello R, Grasso LF, Nachev E, Auriemma RS, Kalinov K \& Zacharieva S 2014 Could different treatment approaches in acromegaly influence life expectancy? A comparative study between Bulgaria and Campania (Italy). European Journal of Endocrinology 171 263-273. (https://doi.org/10.1530/EJE-13-1022)

Couldwell WT \& Cannon-Albright LA 2014 Co-prevalence of other tumors in patients harboring pituitary tumors. Journal of Neurosurgery 121 1474-1477. (https://doi.org/10.3171/2014.8.JNS132139)

Daly AF \& Beckers A 2020 The epidemiology of pituitary adenomas. Endocrinology and Metabolism Clinics of North America 49 347-355. (https://doi.org/10.1016/j.ecl.2020.04.002)

Dekkers OM, Romijn JA, de Boer A \& Vandenbroucke JP 2010 The risk for breast cancer is not evidently increased in women with hyperprolactinemia. Pituitary 13 195-198. (https://doi.org/10.1007/ s11102-009-0214-y)

Dekkers OM, Ehrenstein V, Bengtsen M, Farkas DK, Pereira AM, Sorensen HT \& Jorgensen JO 2015 Breast cancer risk in hyperprolactinemia: a population-based cohort study and metaanalysis of the literature. European Journal of Endocrinology 173 269-273. (https://doi.org/10.1530/EJE-15-0282)

Delgrange E, Vasiljevic A, Wierinckx A, Francois P, Jouanneau E, Raverot G \& Trouillas J 2015 Expression of estrogen receptor alpha is associated with prolactin pituitary tumor prognosis and supports the sex-related difference in tumor growth. European Journal of Endocrinology 172 791-801. (https://doi.org/10.1530/EJE-14-0990)

Doknic M, Pekic S, Civcic M \& Popovic V 2012 Clinical Case Seminar. Peculiar prolactinomas in patients with pituitary developmental gene mutations: from an adult endocrinologist perspective. Hormones $\mathbf{1 1}$ 189-198. (https://doi.org/10.14310/horm.2002.1346)

Duran-Ortiz S, List EO, Basu R \& Kopchick JJ 2021 Extending lifespan by modulating the growth hormone/insulin-like growth factor-1 axis: coming of age. Pituitary 24 438-456. (https://doi.org/10.1007/s11102020-01117-0)

Erfurth EM, Bullow B, Mikoczy Z \& Hagmar L 2001 Incidence of a second tumor in hypopituitary patients operated for pituitary tumors. Journal of Clinical Endocrinology and Metabolism 86 659-662. (https://doi. org/10.1210/jcem.86.2.7234)

Esposito D, Ragnarsson O, Granfeldt D, Marlow T, Johannsson G \& Olsson DS 2018 Decreasing mortality and changes in treatment patterns in patients with acromegaly from a Nationwide Study. European Journal of Endocrinology 178 459-469. (https://doi. org/10.1530/EJE-18-0015)

Esposito D, Ragnarsson O, Johannsson G \& Olsson DS 2021 Incidence of benign and malignant tumors in patients with acromegaly is increased: a nationwide population-based study. Journal of Clinical Endocrinology and Metabolism 106 3487-3496. (https://doi.org/10.1210/ clinem/dgab560)

Forloni F, Giovilli M, Pecis C, Bortolani E, Preziosi A, Barzaghi ME, Corti D \& Beck-Peccoz P 2001 Pituitary prolactin-secreting macroadenoma combined with bilateral breast cancer in a 45 -year-old male. Journal of

This work is licensed under a Creative Commons Attribution 4.0 International License. 
Endocrinological Investigation 24 454-459. (https://doi.org/10.1007/ BF03351047)

Fortunati N, Guaraldi F, Zunino V, Penner F, D’Angelo V, Zenga F, Pecori Giraldi F, Catalano MG \& Arvat E 2017 Effects of environmental pollutants on signaling pathways in rat pituitary GH3 adenoma cells. Environmental Research 158 660-668. (https://doi.org/10.1016/j. envres.2017.07.015)

Fujimoto N 2001 Effects of endocrine disruptors on the pituitary gland. Journal of Toxicologic Pathology 14 65-69. (https://doi.org/10.1293/ tox.14.65)

Gadelha MR, Kasuki L, Lim DST \& Fleseriu M 2019 Systemic complications of acromegaly and the impact of the current treatment landscape: an update. Endocrine Reviews 40 268-332. (https://doi.org/10.1210/ er.2018-00115)

Giustina A, Barkan A, Beckers A, Biermasz N, Biller BMK, Boguszewski C, Bolanowski M, Bonert V, Bronstein MD, Casanueva FF, et al. 2020 A consensus on the diagnosis and treatment of acromegaly comorbidities: an update. Journal of Clinical Endocrinology and Metabolism 105 dgz096. (https://doi.org/10.1210/clinem/dgz096)

Gualtieri A, Kyprianou N, Gregory LC, Vignola ML, Nicholson JG, Tan R, Inoue SI, Scagliotti V, Casado P, Blackburn J, et al. 2021 Activating mutations in BRAF disrupt the hypothalamo-pituitary axis leading to hypopituitarism in mice and humans. Nature Communications 12 2028. (https://doi.org/10.1038/s41467-021-21712-4)

Guevara-Aguirre J, Balasubramanian P, Guevara-Aguirre M, Wei M, Madia F, Cheng CW, Hwang D, Martin-Montalvo A, Saavedra J, Ingles S, et al. 2011 Growth hormone receptor deficiency is associated with a major reduction in pro-aging signaling, cancer, and diabetes in humans. Science Translational Medicine 3 70ra13. (https://doi. org/10.1126/scitranslmed.3001845)

Gullu BE, Celik O, Gazioglu N \& Kadioglu P 2010 Thyroid cancer is the most common cancer associated with acromegaly. Pituitary $\mathbf{1 3}$ 242-248. (https://doi.org/10.1007/s11102-010-0224-9)

Hage M, Viengchareun S, Brunet E, Villa C, Pineau D, Bouligand J, Teglas JP, Adam C, Parker F, Lombès M, et al. 2018 Genomic alterations and complex subclonal architecture in sporadic GH-secreting pituitary adenomas. Journal of Clinical Endocrinology and Metabolism 103 1929-1939. (https://doi.org/10.1210/jc.2017-02287)

Hall WA, Luciano MG, Doppman JL, Patronas NJ \& Oldfield EH 1994 Pituitary magnetic resonance imaging in normal human volunteers: occult adenomas in the general population. Annals of Internal Medicine 120 817-820. (https://doi.org/10.7326/0003-4819-120-10-199405150$00001)$

Hamid N, Junaid M \& Pei DS 2021 Combined toxicity of endocrinedisrupting chemicals: a review. Ecotoxicology and Environmental Safety 215 112136. (https://doi.org/10.1016/j.ecoenv.2021.112136)

Hammarstrand C, Ragnarsson O, Bengtsson O, Bryngelsson IL, Johannsson G \& Olsson DS 2018 Comorbidities in patients with nonfunctioning pituitary adenoma: influence of long-term growth hormone replacement. European Journal of Endocrinology 179 229-237. (https://doi.org/10.1530/EJE-18-0370)

Hamurcu Z, Cakir I, Donmez-Altuntas H, Bitgen N, Karaca Z, Elbuken G \& Bayram F 2011 Micronucleus evaluation in mitogen-stimulated lymphocytes of patients with acromegaly. Metabolism: Clinical and Experimental 60 1620-1626. (https://doi.org/10.1016/j. metabol.2011.03.013)

Han AJ, Varlamov EV \& Fleseriu M 2021 Non-functioning pituitary microadenomas, should imaging interval be extended? A large singlecenter cohort study. Journal of Clinical Endocrinology and Metabolism dgab748. (https://doi.org/10.1210/clinem/dgab748)

Hao S, Huang M, Tian W, Chen Y, Zhao J \& Luo D 2020 Whole exome sequencing in the male breast cancer with prolactinoma: a case report and literature review. Journal of Breast Cancer 23 656-664. (https://doi. org/10.4048/jbc.2020.23.e63)

Heaphy CM, Bi WL, Coy S, Davis C, Gallia GL, Santagata S \& Rodriguez FJ 2020 Telomere length alterations and ATRX/DAXX loss in pituitary adenomas. Modern Pathology 33 1475-1481. (https://doi.org/10.1038/ s41379-020-0523-2)

Hemminki K, Försti A \& Ji J 2007 Incidence and familial risks in pituitary adenoma and associated tumors. Endocrine-Related Cancer 14 103-109. (https://doi.org/10.1677/ERC-06-0008)

Ho K, Fleseriu M, Kaiser U, Salvatori R, Brue T, Lopes MB, Kunz P, Molitch M, Camper SA, Gadelha M, et al. 2021 Pituitary neoplasm nomenclature workshop: does adenoma stand the test of time? Journal of the Endocrine Society 5 bvaa205. (https://doi.org/10.1210/jendso/bvaa205)

Holdaway IM, Rajasoorya RC \& Gamble GD 2004 Factors influencing mortality in acromegaly. Journal of Clinical Endocrinology and Metabolism 89 667-674. (https://doi.org/10.1210/jc.2003-031199)

Huang-Doran I, Kinzer AB, Jimenez-Linan M, Thackray K, Harris J, Adams CL, de Kerdanet M, Stears A, O’Rahilly S, Savage DB, et al. 2021 Ovarian hyperandrogenism and response to gonadotropin-releasing hormone analogues in primary severe insulin resistance. Journal of Clinical Endocrinology and Metabolism 106 2367-2383. (https://doi. org/10.1210/clinem/dgab275)

Ikeno Y, Hubbard GB, Lee S, Cortez LA, Lew CM, Webb CR, Berryman DE, List EO, Kopchick JJ \& Bartke A 2009 Reduced incidence and delayed occurrence of fatal neoplastic diseases in growth hormone receptor/ binding protein knockout mice. Journals of Gerontology: Series A, Biological Sciences and Medical Sciences 64 522-529. (https://doi. org/10.1093/gerona/glp017)

Jenkins PJ \& Besser M 2001 Clinical perspective: acromegaly and cancer: a problem. Journal of Clinical Endocrinology and Metabolism $\mathbf{8 6}$ 2935-2941. (https://doi.org/10.1210/jcem.86.7.7634)

Kasprzak A 2021 Insulin-like growth factor 1 (IGF-1) signaling in glucose metabolism in colorectal cancer. International Journal of Molecular Sciences 22 6434. (https://doi.org/10.3390/ijms22126434)

Kauppinen-Makelin R, Sane T, Reunanen A, Valimaki MJ, Niskanen L, Markkanen H, Loyttyniemi E, Ebeling T, Jaatinen P, Laine H, et al. 2005 A nationwide survey of mortality in acromegaly. Journal of Clinical Endocrinology and Metabolism 90 4081-4086. (https://doi. org/10.1210/jc.2004-1381)

Keshavarz-Maleki R, Kaviani A, Omranipour R, Gholami M, Khoshayand MR, Ostad SN \& Sabzevari O 2021 Bisphenol-A in biological samples of breast cancer mastectomy and mammoplasty patients and correlation with levels measured in urine and tissue. Scientific Reports 11 18411. (https://doi.org/10.1038/s41598-021-97864-6)

Kochukov MY, Jeng YJ \& Watson CS 2009 Alkylphenol xenoestrogens with varying carbon chain lengths differentially and potently activate signaling and functional responses in GH3/B6/F10 somatomammotropes. Environmental Health Perspectives 117 723-730. (https://doi.org/10.1289/ehp.0800182)

Krol MB, Galicki M, Gresner P, Wieczorek E, Jablonska E, Reszka E, Morawiec Z, Wąsowicz W \& Gromadzińska J 2018 The ESR1 and GPX1 gene expression level in human malignant and non-malignant breast tissues. Acta Biochimica Polonica 65 51-57. (https://doi.org/10.18388/ abp.2016_1425)

Krzisnik C, Grguric S, Cvijovic K \& Laron Z 2010 Longevity of the hypopituitary patients from the island Krk: a follow-up study. Pediatric Endocrinology Reviews 7 357-362.

Kulas J, Tucovic D, Zeljkovic M, Popovic D, Popov Aleksandrov A, Kataranovski M \& Mirkov I 2021 Aryl hydrocarbon receptor is involved in the proinflammatory cytokine response to cadmium. Biomedical and Environmental Sciences 34 192-202. (https://doi.org/10.3967/ bes2021.025)

Lasolle H, Elsensohn MH, Wierinckx A, Alix E, Bonnefille C, Vasiljevic A, Cortet C, Decoudier B, Sturm N, Gaillard S, et al. 2020 Chromosomal instability in the prediction of pituitary neuroendocrine tumors prognosis. Acta Neuropathologica Communications 8 190. (https://doi. org/10.1186/s40478-020-01067-5)

Leontiou CA, Gueorguiev M, van der Spuy J, Quinton R, Lolli F, Hassan S, Chahal HS, Igreja SC, Jordan S, Rowe J, et al. 2008 The role of the aryl hydrocarbon receptor-interacting protein gene in familial and sporadic (c) 2022 The authors Published by Bioscientifica Ltd.
This work is licensed under a Creative Commons Attribution 4.0 International License. 
pituitary adenomas. Journal of Clinical Endocrinology and Metabolism 93 2390-2401. (https://doi.org/10.1210/jc.2007-2611)

Levy A 2011 Molecular and trophic mechanisms of pituitary tumourigenesis. Hormone Research in Paediatrics 76 (Supplement 1) 2-6. (https://doi.org/10.1159/000329114)

Levy A \& Lightman S 2003 Molecular defects in the pathogenesis of pituitary tumours. Frontiers in Neuroendocrinology 24 94-127. (https:// doi.org/10.1016/s0091-3022(03)00012-8)

Liby K, Neltner B, Mohamet L, Menchen L \& Ben-Jonathan N 2003 Prolactin overexpression by MDA-MB- 435 human breast cancer cells accelerates tumor growth. Breast Cancer Research and Treatment 79 241-252. (https://doi.org/10.1023/a:1023956223037)

Lim CT \& Korbonits M 2018 Update on the clinicopathology of pituitary adenomas. Endocrine Practice 24 473-488. (https://doi.org/10.4158/ EP-2018-0034)

Lloyd C \& Grossman A 2014 The AIP (aryl hydrocarbon receptorinteracting protein) gene and its relation to the pathogenesis of pituitary adenomas. Endocrine 46 387-396. (https://doi.org/10.1007/ s12020-013-0125-6)

Loeper S \& Ezzat S 2008 Acromegaly: re-thinking the cancer risk. Reviews in Endocrine and Metabolic Disorders 9 41-58. (https://doi.org/10.1007/ s11154-007-9063-z)

Maione L, Brue T, Beckers A, Delemer B, Petrossians P, Borson-Chazot F, Chabre O, François P, Bertherat J, Cortet-Rudelli C, et al. 2017 Changes in the management and comorbidities of acromegaly over three decades: the French Acromegaly Registry. European Journal of Endocrinology 176 645-655. (https://doi.org/10.1530/EJE-16-1064)

Mallawaarachchi CM, Ivanova S, Shorthouse A, Shousha S \& Sinnett D 2011 A rare case of male breast ductal carcinoma in-situ associated with prolactinoma. BMJ Case Reports 2011 bcr0120091421. (https:// doi.org/10.1136/bcr.01.2009.1421)

Maruyama S, Fujimoto N, Yin H \& Ito A 1999 Growth stimulation of a rat pituitary cell line MtT/E-2 by environmental estrogens in vitro and in vivo. Endocrine Journal 46 513-520. (https://doi.org/10.1507/ endocrj.46.513)

McCormack A, Dekkers OM, Petersenn S, Popovic V, Trouillas J, Raverot G, Burman P \& ESE Survey Collaborators 2018 Treatment of aggressive pituitary tumours and carcinomas: results of a European Society of Endocrinology (ESE) survey 2016. European Journal of Endocrinology 178 265-276. (https://doi.org/10.1530/EJE-17-0933)

Melmed S 2020 Pituitary-tumor endocrinopathies. New England Journal of Medicine 382 937-950. (https://doi.org/10.1056/NEJMra1810772)

Mercado M, Gonzalez B, Vargas G, Ramirez C, de los Monteros AL, Sosa E, Jervis P, Roldan P, Mendoza V, López-Félix B, et al. 2014 Successful mortality reduction and control of comorbidities in patients with acromegaly followed at a highly specialized multidisciplinary clinic. Journal of Clinical Endocrinology and Metabolism 99 4438-4446. (https://doi.org/10.1210/jc.2014-2670)

Mian C, Ceccato F, Barollo S, Watutantrige-Fernando S, Albiger N, Regazzo D, de Lazzari P, Pennelli G, Rotondi S, Nacamulli D, et al. 2014 AHR over-expression in papillary thyroid carcinoma: clinical and molecular assessments in a series of Italian acromegalic patients with a long-term follow-up. PLOS ONE 9 e101560. (https://doi.org/10.1371/ journal.pone.0101560)

Minniti G, Traish D, Ashley S, Gonsalves A \& Brada M 2005 Risk of second brain tumor after conservative surgery and radiotherapy for pituitary adenoma: update after an additional 10 years. Journal of Clinical Endocrinology and Metabolism 90 800-804. (https://doi.org/10.1210/ jc.2004-1152)

Molitch ME 2017 Diagnosis and treatment of pituitary adenomas: a review. JAMA 317 516-524. (https://doi.org/10.1001/ jama.2016.19699)

Murphy N, Knuppel A, Papadimitriou N, Martin RM, Tsilidis KK, SmithByrne K, Fensom G, Perez-Cornago A, Travis RC, Key TJ, et al. 2020 Insulin-like growth factor-1, insulin-like growth factor-binding protein-3, and breast cancer risk: observational and Mendelian
(C) 2022 The authors Published by Bioscientifica Ltd. randomization analyses with $\sim 430000$ women. Annals of Oncology 31 641-649. (https://doi.org/10.1016/j.annonc.2020.01.066)

Neou M, Villa C, Armignacco R, Jouinot A, Raffin-Sanson ML, Septier A, Letourneur F, Diry S, Diedisheim M, Izac B, et al. 2020 Pangenomic classification of pituitary neuroendocrine tumors. Cancer Cell 37 123134.e5. (https://doi.org/10.1016/j.ccell.2019.11.002)

Norberg L, Johansson R \& Rasmuson T 2008 Pituitary adenomas in northern Sweden: a study on therapy choices and the risk of second primary tumours. Clinical Endocrinology 68 780-785. (https://doi. org/10.1111/j.1365-2265.2007.03118.x)

Olsson DS, Hammarstrand C, Bryngelsson IL, Nilsson AG, Andersson E, Johannsson G \&, Ragnarsson O 2017 Incidence of malignant tumours in patients with a non-functioning pituitary adenoma. EndocrineRelated Cancer 24 227-235. (https://doi.org/10.1530/ERC-16-0518)

Orme SM, McNally RJ, Cartwright RA \& Belchetz PE 1998 Mortality and cancer incidence in acromegaly: a retrospective cohort study. United Kingdom Acromegaly Study Group. Journal of Clinical Endocrinology and Metabolism 83 2730-2734. (https://doi.org/10.1210/ jcem.83.8.5007)

Parolin M, Dassie F, Russo L, Mazzocut S, Ferrata M, De Carlo E, Mioni R, Fallo F, Vettor R, Martini C, et al. 2018 Guidelines versus real life practice: the case of colonoscopy in acromegaly. Pituitary 21 16-24. (https://doi.org/10.1007/s11102-017-0841-7)

Pekic S, Medic Stojanoska M \& Popovic V 2019a Hyperprolactinemia/ prolactinomas in the postmenopausal period: challenges in diagnosis and management. Neuroendocrinology 109 28-33. (https://doi. org/10.1159/000494725)

Pekic S, Soldatovic I, Miljic D, Stojanovic M, Doknic M, Petakov M \& Popovic V 2019b Familial cancer clustering in patients with prolactinoma. Hormones and Cancer 10 45-50. (https://doi. org/10.1007/s12672-018-0348-3)

Pepe S, Korbonits M \& Iacovazzo D 2019 Germline and mosaic mutations causing pituitary tumours: genetic and molecular aspects. Journal of Endocrinology 240 R21-R45. (https://doi.org/10.1530/JOE-18-0446)

Pesatori AC, Baccarelli A, Consonni D, Lania A, Beck-Peccoz P, Bertazzi PA \& Spada A 2008 Aryl hydrocarbon receptor-interacting protein and pituitary adenomas: a population-based study on subjects exposed to dioxin after the Seveso, Italy, accident. European Journal of Endocrinology 159 699-703. (https://doi.org/10.1530/EJE-08-0593)

Pollak MN, Schernhammer ES \& Hankinson SE 2004 Insulin-like growth factors and neoplasia. Nature Reviews: Cancer 4 505-518. (https://doi. org/10.1038/nrc1387)

Popovic V, Damjanovic S, Micic D, Nesovic M, Djurovic M, Petakov M, Obradovic S, Zoric S, Simic M, Penezic Z, et al. 1998 Increased incidence of neoplasia in patients with pituitary adenomas. The Pituitary Study Group. Clinical Endocrinology 49 441-445. (https://doi. org/10.1046/j.1365-2265.1998.00536.x)

Raggi F, Russo D, Urbani C, Sardella C, Manetti L, Cappellani D, Lupi I, Tomisti L, Martino E, Marcocci C, et al. 2016 Divergent effects of dioxin- or non-dioxin-like polychlorinated biphenyls on the apoptosis of primary cell culture from the mouse pituitary gland. PLOS ONE 11 e0146729. (https://doi.org/10.1371/journal.pone.0146729)

Reincke M, Sbiera S, Hayakawa A, Theodoropoulou M, Osswald A, Beuschlein F, Meitinger T, Mizuno-Yamasaki E, Kawaguchi K, Saeki Y, et al. 2015 Mutations in the deubiquitinase gene USP8 cause Cushing's disease. Nature Genetics 47 31-38. (https://doi.org/10.1038/ng.3166)

Renehan AG, Zwahlen M, Minder C, O’Dwyer ST, Shalet SM \& Egger M 2004 Insulin-like growth factor (IGF)-I, IGF binding protein-3, and cancer risk: systematic review and meta-regression analysis. Lancet 363 1346-1353. (https://doi.org/10.1016/S0140-6736(04)16044-3)

Ritvonen E, Löyttyniemi E, Jaatinen P, Ebeling T, Moilanen L, Nuutila P, Kauppinen-Mäkelin R \& Schalin-Jäntti C 2016 Mortality in acromegaly: a 20-year follow-up study. Endocrine-Related Cancer 23 469-480. (https://doi.org/10.1530/ERC-16-0106)

Rocha PRS, Oliveira VD, Vasques CI, Dos Reis PED \& Amato AA 2021 Exposure to endocrine disruptors and risk of breast cancer: a

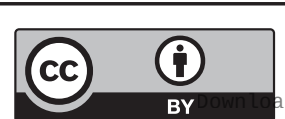

This work is licensed under a Creative Commons Attribution 4.0 International License. 
systematic review. Critical Reviews in Oncology/Hematology 161103330. (https://doi.org/10.1016/j.critrevonc.2021.103330)

Samani AA, Yakar S, LeRoith D \& Brodt P 2007 The role of the IGF system in cancer growth and metastasis: overview and recent insights. Endocrine Reviews 28 20-47. (https://doi.org/10.1210/er.2006-0001)

Sato T, Muto I, Hasegawa M, Aono T, Okada T, Tamura T \& Sakai T 2007 A rare case of invasive ductal carcinoma with hyperprolactinemia. Breast Cancer 14 302-306. (https://doi.org/10.2325/jbcs.14.302)

Sattler MG, van Beek AP, Wolffenbuttel BH, van den Berg G, Sluiter WJ, Langendijk JA \& van den Bergh AC 2012 The incidence of second tumours and mortality in pituitary adenoma patients treated with postoperative radiotherapy versus surgery alone. Radiotherapy and Oncology 104 125-130. (https://doi.org/10.1016/j.radonc.2012.04.024)

Sbiera S, Perez-Rivas LG, Taranets L, Weigand I, Flitsch J, Graf E, Monoranu C-M, Saeger W, Hagel C, Honegger J, et al. 2019 Driver mutations in USP8 wild-type Cushing's disease. Neuro-Oncology 21 1273-1283.

Seccareccia E \& Brodt P 2012 The role of the insulin-like growth factor-I receptor in malignancy: an update. Growth Hormone and IGF Research 22 193-199. (https://doi.org/10.1016/j.ghir.2012.09.003)

Shah MH, Goldner WS, Benson AB, Bergsland E, Blaszkowsky LS, Brock P, Chan J, Das S, Dickson PV, Fanta P, et al. 2021 Neuroendocrine and adrenal tumors, version 2.2021, NCCN Clinical Practice Guidelines in Oncology. Journal of the National Comprehensive Cancer Network 19 839-868. (https://doi.org/10.6004/jnccn.2021.0032)

Shain AH, Yeh I, Kovalyshyn I, Sriharan A, Talevich E, Gagnon A, Dummer R, North J, Pincus L, Ruben B, et al. 2015 The genetic evolution of melanoma from precursor lesions. New England Journal of Medicine 373 1926-1936. (https://doi.org/10.1056/ NEJMoa1502583)

Sherlock M, Reulen RC, Alonso AA, Ayuk J, Clayton RN, Sheppard MC, Hawkins MM, Bates AS \& Stewart PM 2009 ACTH deficiency, higher doses of hydrocortisone replacement, and radiotherapy are independent predictors of mortality in patients with acromegaly. Journal of Clinical Endocrinology and Metabolism 94 4216-4223. (https:// doi.org/10.1210/jc.2009-1097)

Shevah O \& Laron Z 2007 Patients with congenital deficiency of IGF-I seem protected from the development of malignancies: a preliminary report. Growth Hormone and IGF Research 17 54-57. (https://doi. org/10.1016/j.ghir.2006.10.007)

Soto-Pedre E, Newey PJ, Bevan JS \& Leese GP 2017 Morbidity and mortality in patients with hyperprolactinaemia: the PROLEARS study. Endocrine Connections 6 580-588. (https://doi.org/10.1530/EC-17-0171)

Strous GJ, Almeida ADS, Putters J, Schantl J, Sedek M, Slotman JA, Nespital T, Hassink GC \& Mol JA 2020 Growth hormone receptor regulation in cancer and chronic diseases. Frontiers in Endocrinology 11 597573. (https://doi.org/10.3389/fendo.2020.597573)

Suzuki S, Matsuo K, Ito Y, Kobayashi A, Kokumai T, Furuya A, Ueda O, Mukao T, Yano K, Fujieda K, et al. 2021 A mutation of the $\beta$-domain in POU1F1 causes pituitary deficiency due to dominant PIT-1 $\beta$ expression. European Journal of Endocrinology 185 1-12. (https://doi. org/10.1530/EJE-20-1313)

Tapella L, Sesta A, Cassarino MF, Zunino V, Catalano MG \& Pecori Giraldi F 2017 Benzene and 2-ethyl-phthalate induce proliferation in normal rat pituitary cells. Pituitary 20 311-318. (https://doi. org/10.1007/s11102-016-0777-3)

Terzolo M, Reimondo G, Berchialla P, Ferrante E, Malchiodi E, De Marinis L, Pivonello R, Grottoli S, Losa M, Cannavo S, et al. 2017 Acromegaly is associated with increased cancer risk: a survey in Italy.
Endocrine-Related Cancer 24 495-504. (https://doi.org/10.1530/ERC-160553)

Terzolo M, Puglisi S, Reimondo G, Dimopoulou C \& Stalla GK 2020 Thyroid and colorectal cancer screening in acromegaly patients: should it be different from that in the general population? European Journal of Endocrinolology 183 D1-D13. (https://doi.org/10.1530/EJE19-1009)

Tikk K, Sookthai D, Fortner RT, Johnson T, Rinaldi S, Romieu I, Tjønneland A, Olsen A, Overvad K, Clavel-Chapelon F, et al. 2015 Circulating prolactin and in situ breast cancer risk in the European EPIC cohort: a case-control study. Breast Cancer Research 1749. (https://doi.org/10.1186/s13058-015-0563-6)

Trivellin G \& Korbonits M 2011 AIP and its interacting partners. Journal of Endocrinology 210 137-155. (https://doi.org/10.1530/JOE-11-0054)

Trouillas J, Delgrange E, Wierinckx A, Vasiljevic A, Jouanneau E, Burman P \& Raverot G 2019 Clinical, pathological, and molecular factors of aggressiveness in lactotroph tumours. Neuroendocrinology 109 70-76. (https://doi.org/10.1159/000499382)

Tworoger SS, Sluss P \& Hankinson SE 2006 Association between plasma prolactin concentrations and risk of breast cancer among predominately premenopausal women. Cancer Research 66 2476-2482. (https://doi.org/10.1158/0008-5472.CAN-05-3369)

Tworoger SS, Eliassen AH, Zhang X, Qian J, Sluss PM, Rosner BA \& Hankinson SE 2013 A 20-year prospective study of plasma prolactin as a risk marker of breast cancer development. Cancer Research $\mathbf{7 3}$ 4810-4819. (https://doi.org/10.1158/0008-5472.CAN-13-0665)

Vierimaa O, Georgitsi M, Lehtonen R, Vahteristo P, Kokko A, Raitila A, Tuppurainen K, Ebeling TM, Salmela PI, Paschke R, et al. 2006 Pituitary adenoma predisposition caused by germline mutations in the AIP gene. Science 312 1228-1230. (https://doi.org/10.1126/ science.1126100)

Vujovic S, Vujosevic S, Kavaric S, Sopta J, Ivovic M, Saveanu A, Brue T, Korbonits M \& Popovic V 2016 Cancerous leptomeningitis and familial congenital hypopituitarism. Endocrine 52 231-235. (https:// doi.org/10.1007/s12020-016-0868-y)

Waalkes MP, Anver M \& Diwan BA 1999 Carcinogenic effects of cadmium in the Noble (NBL/Cr) rat: induction of pituitary, testicular, and injection site tumors and intraepithelial proliferative lesions of the dorsolateral prostate. Toxicological Sciences 52 154-161. (https://doi. org/10.1093/toxsci/52.2.154)

Wang M, Wu X, Chai F, Zhang Y \& Jiang J 2016 Plasma prolactin and breast cancer risk: a meta-analysis. Scientific Reports 6 25998. (https:// doi.org/10.1038/srep25998)

Watts EL, Fensom GK, Smith Byrne K, Perez-Cornago A, Allen NE, Knuppel A, Gunter MJ, Holmes MV, Martin RM, Murphy N, et al. 2021 Circulating insulin-like growth factor-I, total and free testosterone concentrations and prostate cancer risk in 200000 men in UK Biobank. International Journal of Cancer 148 2274-2288. (https://doi. org/10.1002/ijc.33416)

Wierinckx A, Delgrange E, Bertolino P, François P, Chanson P, Jouanneau E, Lachuer J, Trouillas J \& Raverot G 2018 Sex-related differences in lactotroph tumor aggressiveness are associated with a specific gene-expression signature and genome instability. Frontiers in Endocrinology 9 706. (https://doi.org/10.3389/fendo.2018.00706)

Wildner M 1999 In memory of William of Occam. Lancet 3542172 (https://doi.org/10.1016/S0140-6736(05)77085-9)

Zheng Y, Mo W, Yu Y, Zou D, He X, Xia X \& Hu J 2017 Breast carcinoma associated with prolactinoma: a case report. Cancer Biology and Therapy 18 132-136. (https://doi.org/10.1080/15384047.2017.1294284)

Received in final form 8 November 2021

Accepted 21 December 2021

Accepted Manuscript published online 22 December 2021 https://eo.bioscientifica.com https://doi.org/10.1530/EO-21-0033
(C) 2022 The authors Published by Bioscientifica Ltd.

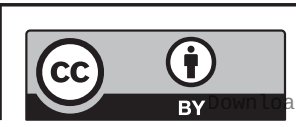

This work is licensed under a Creative Commons Attribution 4.0 International License. A from Bioscientifica,com at 04/26/2023 01:56:25AM 